\title{
電子国土基本図（地図情報）の整備
}

\section{Developing Digital Japan Basic Map (Map Information)}

\section{石関 隆幸* \\ Takayuki ISHIZEKI}

\begin{abstract}
Geospatial Information Authority of Japan (GSI) has started to maintain "Digital Japan Basic Map (Map Information),” and began broadcasting through the Internet since February 2011. Digital Japan Basic Map (Map Information) integrates information necessary for land management, such as topography and structure, into fundamental geospatial data such as roads and buildings for use as the nation's new basic land information, as a new fundamental map in digital age. This report shows some introduction to Digital Japan Basic Map (Map Information).
\end{abstract}

\section{1.はじめに}

地理空間情報活用推進基本法 (以下，「基本法」とい う）の制定と測量法の改正が平成 19 年 5 月に行われ, 前者は同年 8 月，後者は平成20年 4 月に施行された。 これにより，デジタル測量成果の提供や活用に関する 位置づけが法的に明確となった。また，法律レべルで 我が国の地理空間情報の活用推進に関する基本理念が 定められ，その理念に基づく取組が国に求められるこ とになり，平成20年 4 月には地理空間情報活用推進基 本計画が閣議決定された。

国土地理院では，基本法の制定を踏まえて基本困の 体系を見直し，基本法において「位置の基準」と規定 されている基盤地図情報に整合するように，地形，構 造物等の国土管理等に必要な情報を統合した「電子国 土基本困 (地困情報)」を構築・整備し，新たなデジ夕 ル時代の基本図と位置づけた（国土地理院技術協議会 地理空間情報体系分科会，2008）。

\section{2. 紙地図に関するこれまでの課題}

伊能忠敬に始まる我が国の近代地図整備に向けた国 家的取組は，国土地理院及びその前身である陸地測量 部等の基準点測量や基本困整備事業により, 縮尺 5 万

*国土地理院

Geospatial Information Authority of Japan

「写真测量とリモートセンシング」VOL. 50, NO. 1, 2011
分 1 や 2 万 5 千分 1 の地形図として結実した。これら の地形図は，国土の変遷の継続的な記録ととともに， 国土の開発·保全をはじめとした適切な国土管理の推 進や迅速な災害対応，さらには国土の範囲の明示とい う国家の本質に関わる重要な役割を果たしてきた。

しかし, これらの地形困は, 紙に印刷された地図(以 下，「紙地図」という）であるために，地理空間情報の 高度な活用という観点からは, 以下のような様々な制 約を受けるものとなっている。

\section{1 位置精度の制約}

これまでの地形図には, 実社会が紙という限られた 空間に凝縮して記録されていると同時に，人間が目で 見て理解できるような方法（四式）により表現されて いる。したがって，本来描かれるべき位置（真位置） から，図式に基づき意図的にずらして表記（転位）す る場合があるため, 地図の位置精度は, その縮尺に基 づく測量精度よりも局所的に低下している。

しかし，最近の GPS 等による測位技術の高度化と 普及により, 一般の地図利用者でも, 高い位置精度を 有する地理空間情報を取得し，地形図と一緒に活用す ることが可能となってきた。

\section{2 空間解像度の制約}

地形図は，全国統一の仕様で作成され，また空間解 
像度が中縮尺レベルに留まっており，地物が総描され ることもあるため, 個別の建物など, 都市部の詳細な 地理空間情報を把握することには適しておらず，ニー ズに十分対応できていない。

しかし，近年特に都市部を中心に地理空間情報の活 用が拡大し，個々の建物などの詳細な情報活用が求め られてきている。

\section{3 時間精度の制約}

現実世界の変化が地形図に反映されるまでには測量 や地困調製のための一定の時間が必要である。また， 紙地図では，印刷，刊行及び流通に伴う時間が不可避 となり，情報の新鮮さが犠牲になる。

しかし，地形図に表記される情報は，変化が生じた 場合には即座にその変化が反映され, 最新の情報とし て利用できることが理想である。また，カーナビゲー ションシステムの一般化やWeb 上の地図の普及, さ らには携帯端末での地理空間情報活用の急速な進展に 伴い，現実世界との同期に対する利用者側の要求が高 まっている。

\section{3 . 電子国土基本図（地図情報）}

\section{1 電子国土基本図}

地図上の地名や地理空間情報の定義，取得基準等が 情報の整備者ごとに異なると当該情報の利用者が混乱 することから，国土地理院では電子地四により国土を 表す際の基準として，また幅広い目的で共用されるデ ジタルデータの地理空間情報として, 平成21年度より 「電子国土基本図」の整備を行っている。

電子国土基本困は，電子地困上の位置の基準である

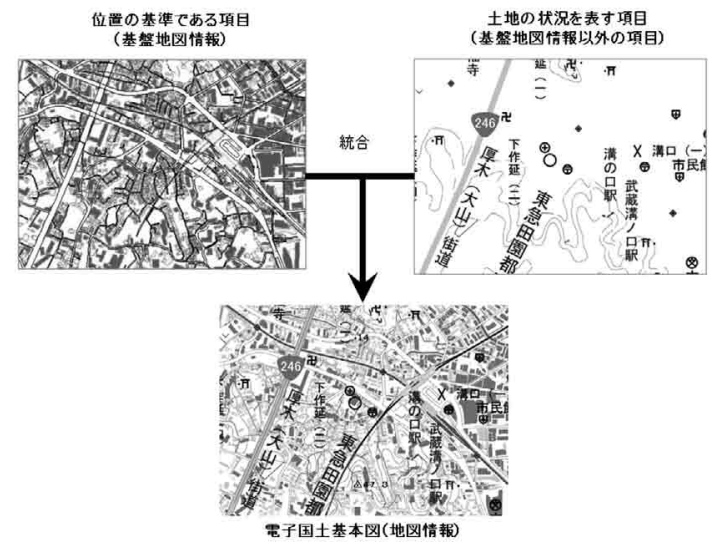

図－1 電子国土基本図（地図情報）の概要
基盤地図情報の道路・建物等の項目と, これまで地形 困に表示してきた植生・崖・岩・構造物等の土地の状 況を表す情報とを統合した「電子国土基本図（地困情 報)」(図一-1)，デジタル空中写真を正射投影した「電 子国土基本困 (オルソ画像)」及び標準地名や通称・位 置・範囲の情報に地理識別子を付与した「電子国土基 本困 (地名情報)」の 3 種類の情報で構成される。

電子国土基本困を整備することにより，位置情報と 詳細な個々の建物・名称等を活用した位置案内や， 3 次元情報を活用した環境・景観シミュレーション, 災 害時の被災地の把握や復興計画の立案など, 様々な場 面でのより高度な活用が可能となる。

なお，地図情報は，2 万 5 千分 1 地形図に替わる新 たな基本図（ベクトルデータ）と位置づけられる。

\section{2 電子国土基本図（地図情報）の精度}

電子国土基本図（地図情報）は，「縮尺レベル25000」 の精度に限定することなく, より精度の高いものを含 んだ，我が国全域を覆うべクトル形式の基盤データで ある。我が国における今後の電子地罒の骨格を定める 基盤地罒情報について，その基準を規定する平成19年 国土交通省令第78号では，基盤地困情報の精度が都市 計画区域内外で異なるものとして規定されている。つ まり，基盤地困情報は全国統一精度に基づいて整備さ れるものではない。結果として基盤地困情報に基づい て整備されていく電子国土基本図（地困情報）は，全 国統一精度にはならない。都市計画区域内では, 基盤 地罒情報をそのまま用いるため位置精度は2,500レべ ル以上，国土や地域の管理上重要な平野部及び離島の うち都市計画区域外については5,000レベル以上, それ 以外の地域については25,000レベル以上で整備され る。

このように，基本法の目指す地理空間情報の高度な 活用を推進していく過程において，国はデジタル化へ の取組の加速，施策の選択と集中，基盤地困情報と一 体となった電子国土基本困 (地困情報) の継続的な精 度向上が求められていくことになる。

\section{4 . 電子国土基本図（地図情報）の取得基準・表示基 準の策定}

\section{1 取得基準・表示基準の検討の経緯と基本コンセプ 卜}

電子国土基本図（地図情報）の整備に向け，取得基 
準や標準的な表示基準について，検討を行った。

検討に当たっては，国土地理院内における検討とと もに，外部有識者からの専門的な意見の聴取を行う場 として, 地図情報検討委員会（委員長：森田喬法政大 学教授）を設置した。また，試作図を作成し，地方公 共団体や地理学に関わる教員 (大学, 高校, 中学校), 測量・地図・GIS 関係の団体・企業・個人を対象にア ンケート調査を行った。

取得基準・表示基準の検討においては，以下の基本 コンセプトを念頭に置いた。

・全ての地物を真位置で取得し, 全ての地物について 転位・総描を排除する

- 2 万 5 千分 1 地形図における,「長さ $25 \mathrm{~m}$ 以上のも のから表示を考慮して取捨選択」のような, 不明瞭 な取捨選択を行わない

・主観的判断を要する基準（「著名なもの」「主要なも の」など）を原則排除する

・デジタルデータによる提供が主体であるため, 外字 フォントを作成しない

\section{2 取得基準・表示基準の概要}

上記の検討の結果，取得基準では， 2 万 5 千分 1 地 形図と比較して，新規に公園（災害対応や都市環境の 把握に使用する), 踏切（立体交差と区別する）, 大規 模な民間建物（ショッピングセンター等）の名称など を取得し，送電線・変電所などを削除した。

また，表示基準では，小学校と中学校で記号のサイ ズを区別する (避難所等で区別が必要)，国道番号を道 路標識と同じ形の記号にする，鉄道の駅名を漢字表記 にする，などを定めた。

なお，取得基準・表示基準の詳細については，伊東 ほか（2009）を参照いただきたい。

\section{5 ，電子国土基本図（地図情報）の更新}

\section{1 更新方法}

電子国土基本図（地図情報）の更新は，国及び地方 公共団体などが行う国土管理，危機管理，環境対策な どに必要不可欠な情報であることから，基盤地困情報 や電子国土基本図（オルソ画像）の整備や更新と連携 して効率的な修正を行いながら整備する。特に，道路 や大規模建築物などの主要な項目に新たな変化が生じ た場合は，公共測量成果や国及び地方公共団体などか ら資料収集を行い，迅速に更新する。

\section{表 -1 即時修正・定期修正項目}

\begin{tabular}{|l|l|}
\hline 即時修正 & 道路（都道府県道以上） \\
& 鉄道 \\
& 水涯線 \\
& 夕゙ム \\
& 大規模建物・高層建物\% \\
& 基準点 \\
& 基本情報調查（石井，2009）の対象項目 \\
& $\begin{array}{l}\text { 行政界・自然地名など） } \\
\text { 資料等から修正可能なもの } \\
\text { (高塔・煙突・温泉など） }\end{array}$ \\
\hline $\begin{array}{l}\text { 定期修正 } \\
\text { 項目 }\end{array}$ & $\begin{array}{l}\text { 即時修正対象外のもの } \\
\end{array}$ \\
\hline
\end{tabular}

※以下のものが対象

・新たに建設された延べ床面積 $3,000 \mathrm{~m}^{2}$ 以上の公共建物

・店舗面積 $10,000 \mathrm{~m}^{2}$ 以上の大規模小売店舗

・高さ $60 \mathrm{~m}$ 以上の高層建物

\section{2 即時修正}

道路・鉄道・大規模建物・行政界などの主要項目が 現況に適合しなくなった場合に，変化を迅速にデー夕 化し，修正を行う（以下，「即時修正」という）。即時 修正の対象項目は表一 1 に示すものである。

即時修正では，関係機関・地方公共団体等の資料 (工 事図面など）や陸域観測技術衛星「だいち」の画像, 基本情報調査の成果等を収集次第，即時に該当デー夕 を修正する。特に, 即時修正項目のうち, 高速道路, 直轄国道，及び鉄道の新設については，開通日等と同 時，それ以外の都道府県道以上の道路，水涯線，夕゙ム， 大規模建物及び高層建物については迅速に更新する。

\section{3 定期修正}

即時修正対象外の項目については，電子国土基本図 (オルソ画像) 等を用いて変化部分を抽出して修正を行 う（以下，「定期修正」という）。定期修正は, 電子国 土基本図 (オルソ画像) 等の整備の直後に実施するこ ととしているため，写真撮影と連動した効率的な修正 が行え, 特に都市計画区域及びその周辺においては, 2 万 5 千分 1 地形図に比べて修正周期が短縮され，よ り新鮮な情報を提供できるようになる。

\section{4 基盤地図情報の更新との連携}

基盤地困情報が整備・更新された場合，電子国土基 本図 (地困情報) に基盤地困情報を取り入れるととも に，基盤地困情報に含まれない項目について，基盤地 


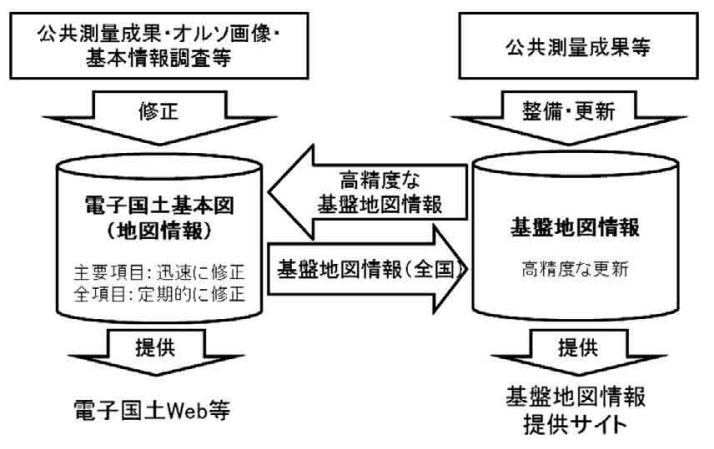

図一２地図情報と基盤地図情報の連携

四情報に位置の基準を合わせる作業を行う。

基盤地図情報が取り込まれた地域において即時修正 または定期修正を行う際には, 当該基盤地図情報の位 置精度を満たすように修正する。修正された電子国土 基本図（地図情報）の基盤地図情報項目は，国土地理 院が整備する基盤地図情報の更新に用いられ，より新 鮮な基盤地図情報を提供できるようになる。

その後, 大縮尺のデジタルデータ等が公共測量成果 等として国土地理院に提出された場合には, デジタル デー夕等を用いて基盤地眓情報の高精度化を行う。高 精度化が行われた基盤地図情報は, 再び電子国土基本 図（地図情報）にそのまま組み込まれ，より高精度な 電子国土基本図（地図情報）を提供できるようになる。

このように，電子国土基本図（地図情報）と基盤地 図情報が連携した更新を行っていくことで，より高精 度かつ新鮮な電子国土基本図（地図情報）が提供でき るようになる (図一 2 )。

\section{6. 電子国土基本図（地図情報）の提供}

電子国土基本図（地困情報）は，道路などの主要な 項目の変化を適宜修正することにより, 可能な限り最 新の情報に更新するとともに，基盤地図情報の高精度 化に併せて位置精度を向上させていくものである。そ こで, 最新情報がそのまま利用者に直接提供されるよ うに，電子国土基本図（地図情報）の提供は，電子国 土 Web システムといった Web 環境による供覧・提供 を予定としている。なお，供覧については平成23年 2 月 1 日より, 電子国土ポータルサイト (http://portal. cyberjapan.jp/index.html）に扔いて供覧を開始した。 また, データの提供については, 準備が整い次第行う 予定である。

また，同一の電子国土基本図（地図情報）を用いて，
現行の基本図体系再編後の基本図体系

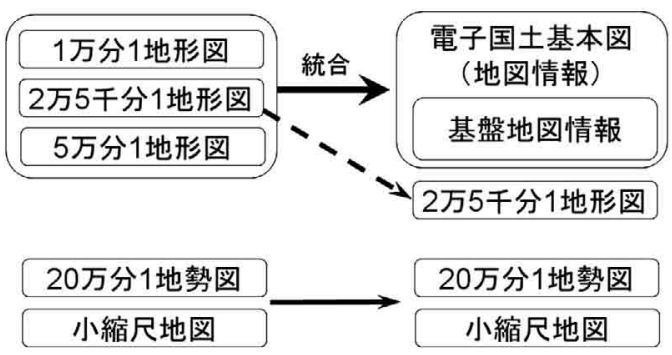

図ー3 現行の基本図体系と新たな基本図体系

大縮尺から 5 万分 1 程度の表示縮尺に対応できるよう な表現方法を開発し，縮尺 1 万分 1 や 5 万分 1 の地形 図が実質的に電子国土基本図（地図情報）に統合され るようにする。 2 万 5 千分 1 地形図（紙地図）につい ては，電子国土基本図を用いて更新部分について総 描・転位等の地困調整を行い, 当面整備・更新を継続 する。20万分 1 地勢図などの小縮尺地図についても， 電子国土基本図を用いて修正を行う（図一 3 )。

\section{7.まとめ}

国土地理院では, 基盤地図情報と整合するように地 形，構造物等の国土管理等に必要な情報を統合した電 子国土基本図（地図情報）を構築・整備し，新たなデ ジタル時代の基本図と位置づけることとした。これは, 第 2 次基本測量長期計画（昭和39年制定）において定 められた 2 万 5 千分 1 地形図を中心とする現行の基本 四体系を 44 年ぶりに見直す大きな変化である。

地図情報を整備することにより，国及び地方公共団 体が，国土管理を適切に実施していくに当たっての必 要不可欠な資料を提供するとともに，国民にデジタル 時代の基本図データとして, 最新かつ信頼性のある データを提供していく。

\section{参考文献}

石井 武(2009）：基本情報調査について, 国土地理院 時報, 118, 73-79.

伊東欣英，干川弘之，石関隆幸，田村栄一，野寺智則 （2009）：電子国土基本図（地図情報）の取得基準, 国土地理院時報, 118, 81-93.

国土地理院技術協議会 地理空間情報体系分科会 （2008）：地理空間情報体系分科会報告書 デジタル 時代の地理空間情報体系の構築一地形図から地理空 間情報へ一。 